\title{
Effects of Political Instability on Economic Growth in the Republic of Congo
}

\section{Emerentienne Bakaboukila Ayessa, Jacques Hakizimana}

Laboratory of Research and Economic and Social Studies (LRES), Faculty of Economic Sciences, Marien Ngouabi University, Brazzaville, Congo

Email: hakizimanajacques46@gmail.com, emerentienne.bakaboukila-ayessa@umng.cg

How to cite this paper: Bakaboukila Ayessa, E., \& Hakizimana, J. (2021). Effects of Political Instability on Economic Growth in the Republic of Congo. Modern Economy, 12, 1896-1912.

https://doi.org/10.4236/me.2021.1212099

Received: November 4, 2021

Accepted: December 20, 2021

Published: December 23, 2021

Copyright (c) 2021 by author(s) and Scientific Research Publishing Inc. This work is licensed under the Creative Commons Attribution International License (CC BY 4.0).

http://creativecommons.org/licenses/by/4.0/ (c) (i) Open Access

\begin{abstract}
The objective of this paper is to analyze the effects of political instability on economic growth in Republic of the Congo. The Autoregressive Lagged Model (ARDL) was used in the study period from 1986 to 2017. The results of this estimation show that political instability is a brake on economic growth. To this end, implications for strengthening policies to promote political stability were formulated.
\end{abstract}

\section{Keywords}

Political Instability, Economic Growth, Congo

\section{Introduction}

Considered the main factor in improving the living conditions of the population (Gérard, 2006) by contributing to job creation (Loots, 1988) and poverty reduction (Sosso et al., 2020), economic growth ${ }^{1}$ is a primary objective of economic policy, and it remains a major concern for policy-makers as well as international institutions.

While the United Nations prescribes an economic growth rate of at least 7\% for developing countries to achieve the Sustainable Development Goals (SDGs), this rate remains well below the $7 \%$ target in these countries. According to a report by the Bank of Central African States, for 2018 and 2019, the economic growth rates were $1.8 \%$ and $2.1 \%$, respectively, for the Economic and Monetary Community of Central Africa (CEMAC). According to the same source, Republic of the Congo showed growth rates (real GDP) of $1.1 \%$ and $-0.3 \%$ in 2018 and

${ }^{1}$ Perroux (1903-1987), Economic growth is the sustained increase over one or more long periods of time of a dimensional indicator for a nation, the aggregate product in real terms, Dictionary of Economic Sciences, Alain Beitone. Page 149. 
2019, respectively.

This low level of economic growth is only getting worse. According to the African Development Bank (ADB, 2021) Africa's GDP contracted by $2.1 \%$ in 2020, constituting the continent's first recession in half a century, while that of Congo contracted by $7.9 \%$. Congo thus ranks first among CEMAC-zone countries heavily affected by the crisis, followed by Equatorial Guinea, which recorded a real GDP contraction of $6.1 \%$ the same year. The decline in real GDP for the entire zone was 2.7 percent.

One factor that may explain economic growth is political instability (Ndokang \& Tsambou, 2019; Gurgul \& Lach, 2013; Alesina et al., 1996). Since gaining independence in 1960, Republic of the Congo has experienced various periods of political instability caused by coups d'état (1963, 1968, 1977), constitutional changes $(2012,2015)$, and unsatisfactory socioeconomic conditions, the index of which decreased from 6.44 in 1985 to 2.5 in 2017 (ICRG) ${ }^{2}$.

In addition, these periods of instability are accompanied by a decline in the level of economic growth, which decreased from $8.4 \%$ in 1961 to $-4.03 \%$ in $1963,-0.62 \%$ in 1977 and $-3.5 \%$ in 2015 . This observation suggests a possible correlation between growth and political instability, which is why it is interesting to examine the effects of political instability on economic growth in Republic of the Congo.

In the economics literature, the effects of political instability on economic growth are controversial both in theory and in empirical work.

At the theoretical level, although authors agree on the idea that the effects of political instability are unfavorable for economic growth, there are divergences regarding the transmission mechanisms. At this level, two groups of thought are identified. The first considers uncertainty the means by which political instability affects economic growth (Barro, 1996; Mauro, 1995; Cukierman et al., 1989). On the other hand, authors in the second group emphasize that in a situation of instability; productive expenditures (investment expenditures) that could promote economic growth are diverted from their objectives and directed toward unproductive military expenditures.

In empirical work, the results are not convergent regarding the effects of political instability on economic growth. Some works establish an inverse relationship between economic growth and political instability (Tabassam et al., 2016), while others show a positive influence of political instability on economic growth (Nadia \& Mouna, 2017; Londregan \& Poole, 1990).

Given the low level of economic growth in Republic of the Congo, the lack of consensus on the effects of political instability on economic growth and the almost nonexistent work examining the relationship between political instability and economic growth in Republic of the Congo, this article seeks to answer the following question: What are the effects of political instability on economic growth in Republic of the Congo?

${ }^{2} \mathrm{~A}$ business guide to political risk for international decisions-Page 27 . 
To this end, the objective is to analyze the effects of political instability on economic growth in Republic of the Congo. The research hypothesis in this work is that political instability has undesirable effects on economic growth in Republic of the Congo.

The rest of this paper is structured as follows. The second section presents the evolution of economic growth and political instability in Republic of the Congo. The third section presents the literature review. The fourth section presents the methodology. The fifth and sixth sections present the results and discussion, respectively, followed by the conclusion and policy implications.

\section{Evolution of Political Instability and Economic Growth from 1986-2017}

In this section, we present the evolution of political instability (Graph 1) and economic growth (Graph 2) in the first step and describe their simultaneous evolution (Graph 3) in the second step.

An analysis of Graph 1 above reveals two periods of fluctuating instability in Republic of the Congo. The first, from 1986 to 2000, shows deterioration in political instability, which reached a below-average level in 1999. The low level of political stability during this period is explained in large part by the events that led to the repeated coups d'état during this period.

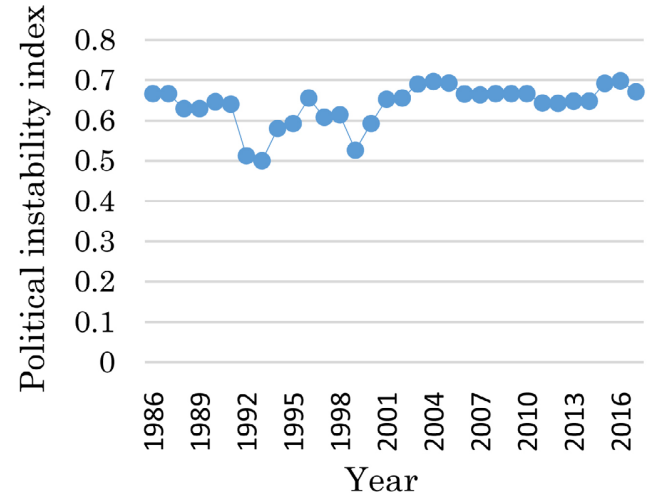

Graph 1. Political instability. Source: authors, using data from WDI and ICR.

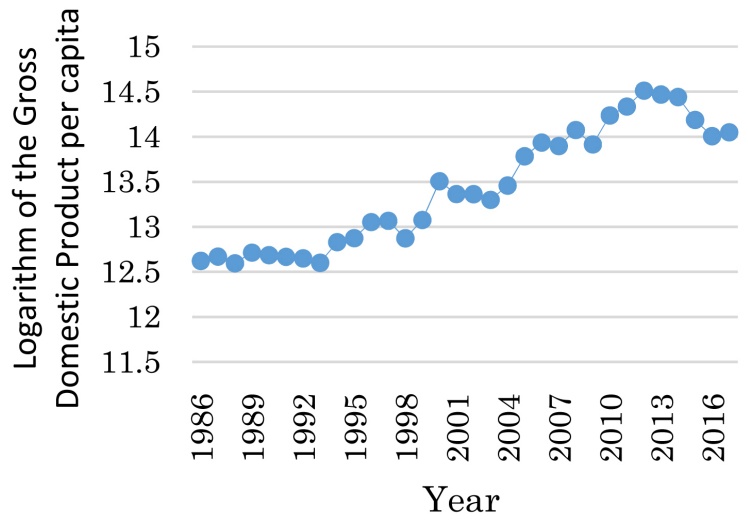

Graph 2. Economic growth. Source: authors, using data from WDI and ICR. 


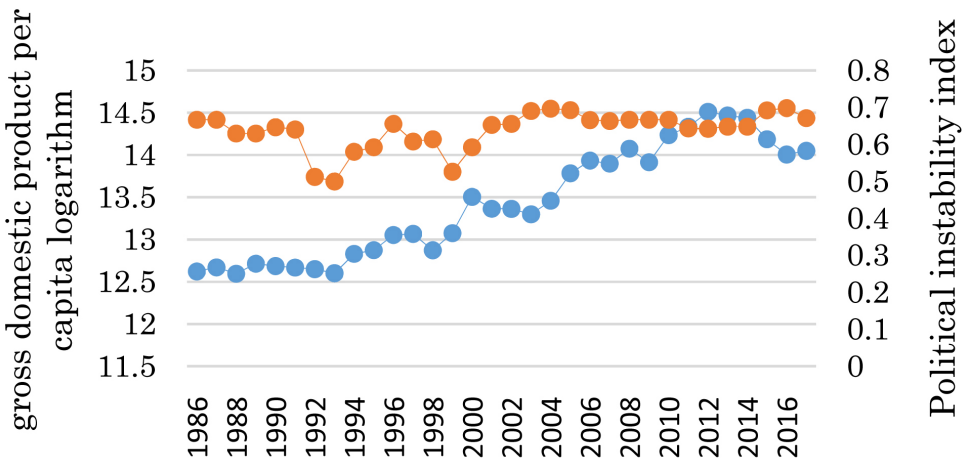

Year

LPIB - INSTPOL

Graph 3. Political instability and economic growth. Source: authors, using data from WDI and ICRG.

Indeed, as early as 1959, violent clashes broke out between the population of the Pool department and that of the North. This led in 1963 to the installation in power of President Alphonse Massamba-Débat (the Congolese Revolution of the "Three Glorious Years"). This conflict claimed many victims, in terms of both physical and human capital, and laid the foundations for the institutionalization of a single party in 1964, followed by a series of coups d'état $(1968,1977,1979$, 1997).

Similarly, although since the acceptance of the capitalist regime in 1991 (with the national conference), the accession to power has occurred through the ballot box (except in 1997), uncivil acts have continued to lead to different forms of instability (The 1992 electoral results revealed worrying geographical divisions directly linked to ethno-regional or departmental groupings in the districts of most of the country's large cities).

In 1993, following an electoral dispute, violence began with the secession of the southern districts. The capital then fell into an urban war aggravated by the actions of militias that were armed by the parties and recruited idle youth (Cobra, Ninja, Zulu, Abbevillois, Cocoille).

In the second period, from 2000 to 2017, a relative improvement in the situation of instability was observed. However, there were some fluctuations, particularly in 2006 and 2016, following disputes related to changes in the constitution and the results of the presidential election. All of these events were at the root of immense losses in terms of physical capital, human capital, and the permanent cessation of certain productive activities by both national and international companies. This has had important consequences for the economic growth of the country.

Economic growth (Graph 2) was characterized by fluctuations during the period considered, although overall, it showed an upward trend.

In Chart 3, the simultaneous analysis shows that as the instability index decreased, i.e., as instability increased, from 1986 to 1999, the level of growth was low. This can be explained by the ethnic and religious conflicts that took place 
immediately after the national conference, i.e., the regime change from a single political party to a democracy (with several political parties), more precisely after the presidential elections.

From 2000 onward, there was an improvement in political instability, which was accompanied by an increase in the level of growth. In general, the two variables of the political instability index and gross domestic product moved in the same direction.

\section{Review of the Literature}

This review focuses on three points: a conceptual review, a theoretical review and an empirical review.

The aim of the conceptual review is to review the different definitions that allow a better understanding of the concept of political instability.

Many researchers in the existing literature have attempted to define political instability, but they cannot find a standard definition that is universally accepted.

According to Fosu (1992) and Abessolo (2003), political instability corresponds to the change in political power through violence and changes in legal forms. It is understood along three axes: elite or executive instability, which includes coups d'état; mass instability, which corresponds to social movements such as strikes; and armed or violent instability, which includes civil war and guerrilla warfare as well as violent political action (Gupta, 1991; Gouenet, 2009).

In the same vein, Alesina (1996) considers political instability the propensity to change government, also taking into account unconstitutional revisions. Barro (1991) equates political instability with the number of political agitations, including the number of military coups.

The International Country Risk Guide (ICRG) considers political instability to include governmental stability, internal conflicts, external conflicts, military presence in politics, religious and ethnic tensions, socioeconomic conditions, investment profiles, corruption, law and order, democratic accountability, and quality of the bureaucracy.

Gakpa (2019) understands political instability through government stability, internal conflicts, external conflicts, and the presence of the military in politics. Barro (1991) argues that many political agitations, including the number of military coups, significantly and negatively affect growth.

Theoretical considerations about the effects of political instability on economic growth agree that political instability has negative effects on economic growth. However, there are still differences of opinion regarding the channels through which political instability affects growth.

From this perspective, Cervantes and Villasenor (2015) consider that political stability influences economic growth through investment, savings, labor market disruption, levels of productivity/output of private agents and the government's monetary and fiscal policies. 
For Muñoz (2009), political instability affects growth through the investment channel (reduced physical and human capital accumulation), sociopolitical unrest (reduced productivity caused by the disruption of normal economic activities), and suboptimal economic policy (political underperformance).

Baklouti and Boujelbene (2020), on the other hand, explain that political instability leads to a disruption of productive activity and an increase in transaction costs that could prevent a country from realizing its true potential, which is essential to achieving economic growth.

On the other hand, Makrem and Faycel (2018) consider that the transition to a more democratic political regime may be accompanied by political instability manifested by strikes, riots, and abrupt governmental changes negatively affecting investment and economic growth.

In empirical work, studies that highlight the effects of political instability on economic growth have produced divergent results. Some show negative effects, while others show positive effects.

Barro (1991) analyzes the link between political instability and economic growth in a panel of 98 countries. He uses a cross-sectional regression with the number of political disturbances and military coups as a proxy for instability. The results of this analysis reveal significant negative effects of political instability on economic growth in these countries.

In addition, Barro and Lee (1994) test the impact of political instability on economic development. They study the growth rates of 116 economies for the period from 1965 to 1985 and find that political instability has negative effects on economic development. Similarly, Haan and Siermann (1996) test whether a lack of political stability has a negative relationship with economic growth and development in the period from 1963 to 1988 with a sample of 96 countries. They conclude that political instability hindered investment in Asia and North America.

Alesina et al. (1996), in the same vein, use a sample of 113 countries and data covering the period 1950-1982. As a measure of political instability, they use the propensity for government change, including unconstitutional overhauls (including coups), in a model in which political instability and economic growth are "jointly determined". The results of their work indicate that during periods of a high propensity for government change, economic growth is lower than in other periods. To arrive at these results, they use the generalized least squares technique.

Aisen and Veiga (2011) consider instability the propensity for government change. Using the system-GMM estimator of dynamic linear models and data covering the period 1960-2004 in a sample of 169 countries, they find that a high level of political instability is associated with a low rate of GDP per capita. This slows the growth of productivity and, to a lesser extent, the accumulation of physical and human capital.

Gurgul and Lach (2013) study the link between political stability and growth 
using panel data for $10 \mathrm{EAC}^{3}$ countries over the period 1990-2009. The authors define political instability as the propensity to change governments (or political instability). They use two variables: a change in the prime minister (major change) and a change in government. The study finds that political instability was detrimental to economic growth.

Farjallah and Abdelhamid (2017), using the autoregressive lagged model (ARDEL) and annual data on the Tunisian economy covering the period from 1984 to 2014, find that political stability, democratic accountability, law and order, and ethnic tensions have positive effects on economic growth.

Makrem and Faycel (2018) examine the nature of the relationship between democracy and growth in a sample of 79 countries over the period 1984-2008 and test whether it depends on political stability. They use the generalized method of moments (GMM) developed for dynamic panel models. They find that political stability is a key variable in determining economic growth. Indeed, the effect of democracy on growth is statistically insignificant in the absence of a stable political framework.

Gakpa (2019) analyzes the impact of the interaction between political instability and foreign direct investment (FDI) on economic growth for 31 sub-Saharan African (SSA) countries. The author introduces an aggregate indicator of political instability constructed using a principal component analysis of several political risk indicators drawn from the ICRG database. A dynamic panel procedure and the triple least squares technique are used to estimate a simultaneous equation model over the period 1984-2015. The model results indicate that political instability affects economic growth both directly and indirectly through its impact on foreign direct investment. The results show that political instability crises hinder economic growth driven by foreign direct investment.

Ndokang and Tsambou (2019) aim to assess the impact of political crises in CAR on the growth performance of the Cameroonian economy. To do so, they rely on a Solow-type growth model augmented with human capital to assess the influence of political instability on growth performance. After using an OLS for a period of 20 years, the econometric analysis shows that political instability in one country has positive effects on the economic health of another country through the reorientation of FDI from one country to another, the level of integration of the subregion and the economic interdependence relationship between them.

From the above review of the literature, it appears that at the theoretical level, the existence of an inverse relationship between political instability and economic growth is unquestionably recognized. However, there are still divergences as to how political instability affects economic growth. On the empirical side, the work is also divergent. Some argue that the results show favorable effects, while others show the opposite. As for the notion of political instability, it is also approached in different ways. To the best of our knowledge, there is no work link${ }^{3}$ Bulgaria, Czech Republic, Estonia, Hungary, Latvia, Lithuania, Poland, Romania, Slovakia and Slovenia. 
ing political instability and economic growth in the Congo. Thus, the contribution of this article lies in the fact that it enriches the economic literature by treating the effects of instability on economic growth in the case of Congo on the one hand and the use of the ARDL technique which is less used in the analysis of the effects of political instability on growth as presented in the empirical review previously presented.

\section{Methodology}

The objective of this paper is to analyze the effects of political instability on economic growth in Republic of the Congo. Our research is based on the growth model proposed by Abessolo (2003). These authors start from a growth model that is based on the Cobb-Douglass production function. Formally, this function is presented as follows:

$$
\mathcal{H}_{t}=\mathcal{A}_{t} \mathcal{M}_{t}^{\lambda} \mathcal{N}_{t}^{1-\lambda}, \text { with, } 0<\lambda<1
$$

$\mathcal{H}_{t}, \mathcal{A}_{t}, \mathcal{M}_{t}$ and $\mathcal{N}_{t}$ are total output, technical progress, the stock of physical capital and labor input at time $t$, respectively. $\lambda$ measures the contribution of capital to output at period $t$, and $1-\lambda$ measures that of labor input at period $t$.

In Equation (1), the returns to scale of the factors capital and labor are constant, and their marginal returns are decreasing. Transforming Equation (1) into a linear function via the logarithmic transformation gives

$$
g_{h}=v g_{m}+(1-v) g_{n}+\psi
$$

In this equation, $g_{h}, g_{m}$ and $g_{n}$ denote the logarithm of production, the logarithm of the capital factor and the logarithm of the labor factor. $\psi$, is the logarithm of technical progress. In Equation (2), the logarithm of technical progress is the only term that cannot be directly determined. It is obtained by determining the difference between the rate of economic growth and the rates of capital and labor factors, i.e.

$$
\psi=g_{h}-v g_{m}-(1-v) g_{n}
$$

In growth theory (Romer, 1986), capital and labor factors are not the only factors that explain growth. Solow (1957) shows that $50 \%$ to $75 \%$ of growth is explained by a residual, although the author does not explain this residual. Nevertheless, some authors, such as Becker (1964) and Lucas (1988), conclude that a substantial part of this residual, known as Solow's residual, can be explained by variations in the quality of factors such as the improvement of the workforce through the increase in the average number of years of training (education (Lucas, 1988)) as well as improved health. Thus, studies based on endogenous growth models have broadened the framework of analysis by including factors that allow the improvement of the labor force, such as training and health, and the accumulated stock of research and development.

Assuming that technical progress is a function of human capital and of the random term representing the various errors that can be made, we have

$$
\psi_{t}=\eta_{1} \mathrm{CH}_{t}+\varepsilon_{t}
$$


Integrating Equation (4) into (2) and considering gross domestic product (GDP) and physical capital (INVST), we obtain the following econometric model:

$$
I P I B_{t}=\beta_{0}+\eta_{1} l C H_{t}+\eta_{2} I I N V S T_{t}+\mu l P O P_{t}+\varepsilon_{t}
$$

In addition to the present explanatory factors of economic growth, ETSIBA et al. (2018) highlight the existence of a strong correlation between economic growth and institutional quality. In this perception, several authors following the example of Barro and Lee (1994), Campos and Karanasos (2008) and Fosu (2002) emphasize political instability, and their work shows that political instability (INSTPOL) is a non-negligible factor explaining economic growth. Considering this variable in Equation (4) gives

$$
I P I B_{t}=\beta_{0}+\varphi I S T P O L_{t}+\eta_{1} I_{C H}+\eta_{2} I I N V S T_{t}+\mu l P O P_{t}+\varepsilon_{t}
$$

Finally, considering that human capital is approximated by the gross primary school enrollment ratio (TBSP), our model for estimation purposes is as follows:

$$
I P I B_{t}=\beta_{0}+\varphi I S T P O L_{t}+\eta_{1} I S B S P_{t}+\eta_{2} I I N V S T_{t}+\mu I P O P_{t}+\varepsilon_{t}
$$

\section{Data source and description of variables}

The data used in this article are secondary data and cover the period from 1986 to 2017. They come from the World Bank's World Development Indicators (WDI) database for gross domestic product per capita (GDP), investment (INVST), population (POPUL) and gross enrollment ratio (GER) at the primary level. The data used to calculate political instability (INSTPOL) are based on the International Country Risk Guide (ICRG). The choice of the study period (1986-2017) is dictated by the availability of data.

The political instability variable used in this article is, as in Gakpa (2019), an aggregate variable obtained by summing six indices (government stability, internal conflict, external conflict, military presence in politics, religious tension and ethnic tension) provided by ICRG. The index is then normalized from zero (0) to one (1). Its interpretation is such that the closer the index is to 1 , the lower the instability is. When the index value is close to 0 , it suggests a situation of strong instability.

Table 1 presents a summary of the variables used, their sources, the authors who have already used them and the expected signs.

Table 2 shows that gross domestic product (GDP), gross primary school enrollment (GPE), investment (INVST) and POPUL are volatile. This volatility is analyzed through the values of their standard deviations, which highlight strong dispersion for each variable. These values are 547,426.4 for GDP, 13.26560 for TBSP, 1.64E+12 for INVST and 927411.7 for POPUL. INSTPOL is the only variable that does not have a large dispersion around its mean. Its standard deviation is 0.050810 .

With regard to the normality of the series, the descriptive statistics show that only the variables GDP and POPUL are normally distributed (probability of the Jarque-Bera statistic $>5 \%$ ). The other variables have a probability of the 
Table 1. Summary of variables, sources, authors and signs.

\begin{tabular}{ccccc}
\hline Variable & Abbreviation & Source & Authors & Sign \\
\hline $\begin{array}{c}\text { Gross domestic } \\
\text { product per capita }\end{array}$ & PIB & BM & Al Qudah et al. (2020) & - \\
Political instability indices & INSTPOL & ICRG & Abessolo (2003) & Positive \\
Investment & INVST & BM & Makrem \& Faysel (2018) & Positive \\
Population & POPUL & BM & Aisen \& Veiga (2011) & Positive \\
Gross enrollment ratio & TBSP & BM & Kouassi (2021) & Positive \\
\hline
\end{tabular}

Source: authors, from the literature.

Table 2. Descriptive statistics.

\begin{tabular}{cccccc}
\hline & PIB & INSTPOL & INVST & POPUL & TBSP \\
\hline Average & $839,208.8$ & 0.638262 & $1.42 \mathrm{E}+12$ & $3,408,768$ & 89.80832 \\
Maximum & 200,2846 & 0.698302 & $5.67 \mathrm{E}+12$ & $5,110,701$ & 117.5346 \\
Minimum & $295,322.1$ & 0.500000 & $1.11 \mathrm{E}+11$ & $2,112,359$ & 36.76923 \\
Standard deviation & $547,426.4$ & 0.050810 & $1.64 \mathrm{E}+12$ & $927,411.7$ & 13.26560 \\
Jarque-Bera & 3.652343 & 11.75830 & 8.476961 & 2.367143 & 76.28276 \\
Probability & 0.161029 & 0.002797 & 0.014430 & 0.306183 & 0.000000 \\
Observations & 32 & 32 & 32 & 32 & 32 \\
\hline
\end{tabular}

Source: authors, based on WDI and ICRG data.

Jarque-Bera statistic less than $5 \%$, which means that they do not follow a normal distribution. However, based on the law of large numbers, we can affirm that all series tend toward a normal distribution with respect to the number of observations $\mathrm{n}(\mathrm{n}>25)$.

\section{Estimation procedure}

\section{Stationarity of the series}

In addition to the requirement of a normal distribution of a series, another necessary and mandatory condition in studies using time series data is the stationarity of the series. Indeed, a nonstationary series (one whose mean and variance vary with time), if not treated (made stationary), can lead to biased results (spurious regression).

In the context of a time series, several tests are used to test stationarity (existence or not of a unit root). These include the augmented Dickey-Fuller test (ADF), the Phillippe-Perron test (PP), the Andrews and Zivot test (AZ), the Ng-Perron test, and the KPSS test, the first two of which are the most commonly used. In this research, the ADF test and the PP test are used, and the results are summarized in Table 3. 
Table 3. Stationarity.

\begin{tabular}{ccccc}
\hline \multirow{2}{*}{ variables } & \multicolumn{2}{c}{ In level } & \multicolumn{2}{c}{ In first difference } \\
\cline { 2 - 5 } & ADF & PP & ADF & PP \\
\hline \multirow{2}{*}{ LPIB } & 1.527337 & -0.867669 & $-4.988341^{* * *}$ & $-4.98896^{* * *}$ \\
& $(0.9658)$ & $(0.7849)$ & $(0.0000)$ & $(0.0000)$ \\
INSTPOL & -0.155054 & -0.024424 & $-5.548321^{* * *}$ & $-7.839214^{* * *}$ \\
& $(0.6221)$ & $(0.6669)$ & $(0.0000)$ & $(0.0000)$ \\
LINVST & 1.404386 & 1.382660 & $-4.323247^{* * *}$ & $-4.323247^{* * *}$ \\
& $(0.9568)$ & $(0.9550)$ & $(0.0001)$ & $(0.0001)$ \\
LPOPUL & $-3.860662^{* *}$ & 31.46028 & $-3.322080^{* *}$ & -0.340505 \\
& $(0.0279)$ & $(0.9999)$ & $(0.0866)$ & $(0.5539)$ \\
LTBSP & $-4.041408^{* * *}$ & $-3.994739^{* * *}$ & $-6.436072^{* * *}$ & $-14.40056^{* * *}$ \\
& $(0.0039)$ & $(0.0044)$ & $(0.0000)$ & $(0.0000)$ \\
\hline
\end{tabular}

Source: authors, based on WDI and ICRG data. Values in parentheses represent probabilities. ${ }^{*}{ }^{* *},{ }^{* *}$; indicates significance at the $10 \%, 5 \%$ and $1 \%$ level, respectively.

From the analysis of the results of the different stationarity tests presented in Table 3 above, we note that the variables LPOPUL and LTBSP are stationary in level (absence of unit root) at least according to one test. They are therefore integrated of order I (0). The LPIB, INSTPOL and LINVST series have a unit root but become stationary in the first difference. They are therefore integrated of I (1).

Since the series are not stationary at the same level i.e., are integrated at different orders, some at I (0) and others at I (1) the standard cointegration tests of Engel and Granger (multivariate case) and Johansen become ineffective, and the Bound test is preferable according to Pesaran et al. (2001). To this end, the use of the autoregressive staggered lag model (ARDL) ${ }^{4}$ is justified.

Compared to other models, the staggered lag autoregressive model has the advantage of being able to estimate short-term dynamics and long-term effects for cointegrated or even integrated series at different orders (Pesaran \& Shin, 1999; Pesaran \& Smith, 1995). Moreover, it is appropriate in the case of small sample series.

In the staggered lag autoregressive model, the cointegration test at the bounds (bound test) is in two steps, the first of which consists of determining the optimal lag through the Akaike criterion (AIC) and the use of the Fisher test. Graph 4 (optimal model) shows the optimal model among the first twenty models chosen according to the Akaike criterion.

\section{$>$ Optimal offset: Optimal model}

${ }^{4}$ For staggered lag autoregressive model development, see Kuma (2018) in "ARDL Modeling, Boundary Cointegration Testing, and the Toda-Yamamoto Approach: elements of theory and practice on software". 


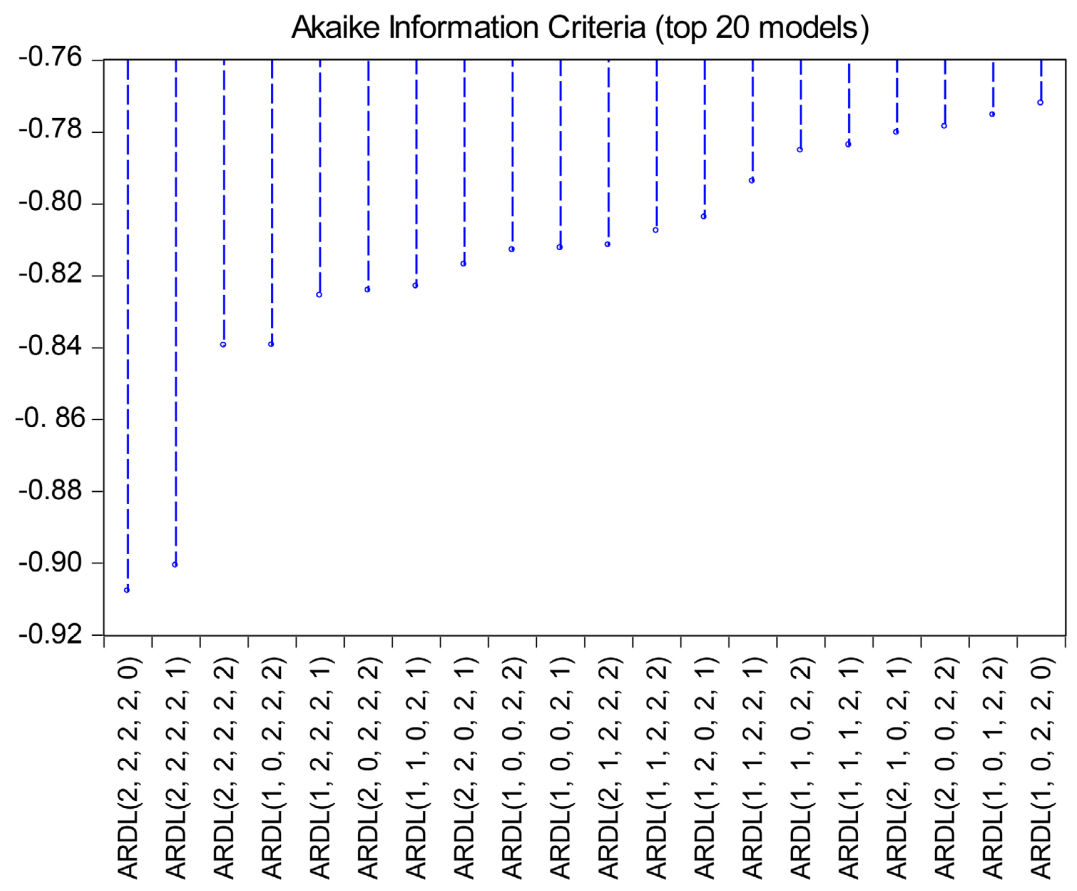

Graph 4. Choice of the optimal model. Source: authors, based on WDI and ICRG data.

According to the above graph, the $\operatorname{ARDL}(2,2,2,2,0)$ model is the best among the twenty presented; it presents the smallest AIC value, which suggests that this model involves less information loss than the other nineteen.

\section{Result of the terminal cointegration test}

Once the results of the test have been obtained, a decision is made by comparing the calculated test statistics, i.e., the value of Fisher's F, with the critical values constituted by the boundary values. Thus, for each threshold:

If Fisher's $\mathrm{F}$ is >the upper bounds, cointegration exists;

If Fisher's $\mathrm{F}$ is $<$ the lower bound, no cointégration exists;

If Fisher's $\mathrm{F}$ is $<$ the lower bound, there is no conclusion.

Table 4 gives the synthesis of the results of the cointegration test at the bounds.

The results of the cointegration test at the bounds confirm the nonexistence of cointegration relationships between the series under study (the value of the F-stat is < that of the upper bound, i.e., $3.539526<4.37$ ). This allows us to estimate the dynamic short-run effects of political instability on economic growth. Table 5 presents the results of the estimation of these effects.

\section{Discussion of the results}

Before discussing the results of this research, it is important to reassure ourselves of the validity of the model from which they were derived. This validity is analyzed through the results of various post estimation tests: the error self-correction test (LM test), the normality test of the residuals Jarque-Bera), the heteroscedacity test, the Ramsay specification test, and the stability test (CUSUM test). Table 6 presents a summary of some of these tests. 
Table 4. Result of the cointegration test: Bound test.

\begin{tabular}{ccc}
\hline Statistical test & Value & $\mathbf{k}$ \\
\hline F-statistic & $\mathbf{3 . 5 3 9 5 2 6}$ & 4 \\
& Critical value at the limits & \\
Significance threshold & Lower bound & Upper bound \\
$10 \%$ & 2.2 & 3.09 \\
$5 \%$ & 2.56 & 3.49 \\
$2.5 \%$ & 2.88 & 3.87 \\
$1 \%$ & 3.29 & $\mathbf{4 . 3 7}$ \\
\hline
\end{tabular}

Source: Authors, based on WDI and ICRG data.

Table 5. Estimation results for effects of political instability on economic growth.

\begin{tabular}{ccccc}
\hline Variable & Coefficient & Std. Error & $t$-Statistic & Probability \\
\hline LPIB(-1) & $0.494055^{* *}$ & 0.206260 & 2.395304 & 0.0284 \\
LPIB(-2) & $-0.484257^{\star}$ & 0.245698 & -1.970943 & 0.0652 \\
INSTPOL & $1.535334^{*}$ & $\mathbf{0 . 8 1 8 0 7 1}$ & $\mathbf{1 . 8 7 6 7 7 2}$ & $\mathbf{0 . 0 7 7 8}$ \\
INSTPOL(-1) & -0.007090 & 1.012762 & -0.007002 & 0.9945 \\
INSTPOL(-2) & $2.201862^{* *}$ & $\mathbf{0 . 9 4 4 7 1 1}$ & $\mathbf{2 . 3 3 0 7 2 3}$ & $\mathbf{0 . 0 3 2 3}$ \\
LINVST & $0.244585^{*}$ & 0.133092 & 1.837717 & 0.0836 \\
LINVST(-1) & 0.222398 & 0.161268 & 1.379057 & 0.1858 \\
LINVST(-2) & $-0.333456^{* *}$ & 0.123031 & -2.710339 & 0.0149 \\
LPOPUL & $-118.8480^{* * *}$ & 38.64908 & -3.075050 & 0.0069 \\
LPOPUL(-1) & $227.3170^{* * *}$ & 71.13981 & 3.195353 & 0.0053 \\
LPOPUL(-2) & $-107.1649^{* * *}$ & 33.47280 & -3.201549 & 0.0052 \\
LTBSP & -0.271740 & 0.187674 & -1.447939 & 0.1658 \\
C & -10.76942 & 6.764608 & -1.592024 & 0.1298 \\
Coefficient of determination (R2) & & & 0.975628 \\
Adjusted coefficient of determination & & & 0.958425 \\
Fisher statistic (F) & & & 56.71119 \\
Probability & & & 0.000000 \\
\hline
\end{tabular}

Source: Authors, based on WDI and ICRG data. ${ }^{*},{ }^{* *},{ }^{* *}$; indicates significance at the $10 \%, 5 \%$ and $1 \%$ level, respectively.

Table 6. Results of the validation tests of the ARDL model $(2,2,2,2,0)$.

\begin{tabular}{cccc}
\hline Type of test & Tests & Valeur & Probability \\
\hline Autocorrelation & Breusch-Godfrey & 1.557550 & 0.2429 \\
Heteroskedasticity & Breusch-Pagan-Godfrey & 0.721490 & 0.7136 \\
Normality & Jarque-Bera & 0.120966 & 0.554211 \\
Specification & Ramsey (Fisher) & 0.326147 & 0.7485 \\
\hline
\end{tabular}

Source: Authors, based on WDI and ICRG data. 
These results of the different post-estimation tests highlight the acceptance of the null hypothesis in each case, as the respective probabilities are greater than $5 \%$. A coefficient of determination (R2) equal to 0.9756 means that the variability of economic growth is explained by the selected variables at approximately $97.56 \%$. In sum, all of the different tests show that the model is of good quality, and therefore, the results that emerge can be discussed.

The analysis of the results (Table 5) highlights a major lesson: political instability is a brake on economic growth in Republic of the Congo.

This statement is justified by the fact that the coefficient associated with the index of the variable LINSTPOL is positive and significant at the $10 \%$ level. This suggests that an increase in the political instability index of 1.5 and 2.2 points at times $t$ and $t-2$, respectively, all other things being equal, is accompanied by an improvement in economic growth of $1 \%$.

The present results obtained in the case of Congo corroborate those obtained by Farjallah and Abdelhamid (2017) in their study conducted in Tunisia. However, they go against those obtained by authors such as Gakpa (2019), Ndokang and Tsambou (2019) in their work carried out in thirty-one (31) countries of Sub-Saharan Africa (SSA), in the Central African Republic, and in forty-nine (49) developing countries, respectively.

\section{Conclusion and Policy Implications}

The objective of this paper was to analyze the effects of political instability on economic growth in Republic of the Congo. The result obtained using an autoregressive lag model (ARDL) and annual data covering the period from 1986 to 2017, taken from the World Development Indicators (WDI) database for macroeconomic variables and from the International Country Risk Guide (ICRG) for variables used in the construction of the political instability indicator show that political instability has a significant negative impact on economic growth in the Republic of the Congo, thus hindering economic growth.

In light of this result, economic policy implications can be formulated. Measures must be strengthened to reduce political instability in the country.

These measures could include strengthening cohesion between the different ethnic groups, the absence of which causes mistrust between them. This mistrust can lead to internal unrest that undermines the functioning of the productive apparatus and, consequently, causes a decline in economic growth. Similarly, strengthening democracy and improving socioeconomic conditions would significantly reduce the level of instability, according to ICRG data.

Since political instability is a concept that manifests itself through several factors, the consideration of an aggregate indicator in this work could be a limitation of the present results insofar as they do not provide information on the component for which economic growth becomes more sensitive. Thus, our future work will be conducted in such a way as to disaggregate instability by focusing on mass instability (instability that corresponds to social movements such as strikes, demonstrations or riots). 


\section{Conflicts of Interest}

The authors declare no conflicts of interest regarding the publication of this paper.

\section{References}

Abessolo, Y. (2003). Instabilité politique et performance économique: Une évaluation du cas du Tchad. Yaoundé II. http://harribey.u-bordeaux4.fr/colloques/abessolo.pdf

African Development Bank (ADB) (2021). From Debt Resolution to Growth: The Road Ahead for Africa.

Aisen, A., \& Veiga, F. J. (2011). How Does Political Instability Affect Economic Growth (Vol. 2011)? IMF Working Papers, International Monetary Fund. https://doi.org/10.5089/9781455211906.001

Al Qudah, A., Zouaoui, A., \&Aboelsoud, M. E. (2020). Does Corruption Adversely Affect Economic Growth in Tunisia? ARDL Approach. Journal of Money Laundering Control, 23, 38-54. https://doi.org/10.1108/JMLC-12-2018-0076

Alesina, A., Ozler, S., Roubini, N., \& Swagel, P. (1996). Political Instability and Economic Growth. Journal of Economic Growth, 1, 189-211. https://doi.org/10.1007/BF00138862

Baklouti, N., \& Boujelbene, Y. (2020). An Econometric Study of the Role of the Political Stability on the Relationship between Democracy and Economic Growth. Panoeconomicus, 67, 187-206. https://doi.org/10.2298/PAN170308015B

Barro, R., \& Lee, J. (1994, September 29). Dataset for a Panel of 138 Countries (Vol. 138). https://www.nber.org/pub/barro.lee/readme.txt

Barro, R.-J. (1991). Economic Growth in a Cross-Section of Countries. Quarterly Journal of Economics, 106, 407-443. https://doi.org/10.2307/2937943

Barro, R.-J. (1996). Democracy and Growth. Journal of Economic Growth, 1, 1-27. https://doi.org/10.1007/BF00163340

Becker, G. (1964). Human Capital: A Theoretical and Empirical Analysis with Special Reference to Education. Columbia University Press.

Campos, N. F., \& Karanasos G. M. (2008). Growth, Volatility and Political Instability: Non-Linear Time-Series Evidence for Argentina, 1896-2000. Economics Letters, 100, 135-137. https://doi.org/10.1016/j.econlet.2007.12.013

Cervantes, R., \& Villaseñor, J. (2015). Political Stability and Economic Growth: Some Considerations. Journal of Public Governance and Policy: Latin American Review, 1, 77-100.

Cukierman, A., Edwards, S., \& Tabellini, G. (1989). Seigniorage and Political Instability. Working Paper No. w3199, National Bureau of Economic Research. https://doi.org/10.3386/w3199

Etsiba, S., Ndombi Avouba, F. G., \& Bozongo, J. C. (2018). Effets de la gouvernance institutionnelle sur la croissance economique: Cas de la cemac. Annales de l'universite Marien N'gouabi, 18, 138-148.

Farjallah, N., \& Abdelhamid, M. (2017). Effet de l'instabilité des institutions politiques sur la croissance économique en Tunisie: Une approche par le modèle ARDL. International Journal of Economics \& Strategic Management of Business Process (ESMB), 8, 148-157.

Fosu, A. K. (1992). Political Instability and Economic Growth: Evidence from Sub-Saharan Africa. Economic Development and Cultural Change, 40, 829-841. https://doi.org/10.1086/451979

Fosu, A. K. (2002). Political Instability and Economic Growth: Implications of Coup 
Events in Sub-Saharan Africa. American Journal of Economics and Sociology, 61, 329-348. https://doi.org/10.1111/1536-7150.00162

Gakpa, L., L. (2019). Instabilité politique, IDE et effets sur la croissance économique dans les pays d'Afrique subsaharienne: un modèle à équations simultanées dynamiques. Region et Development, 50, 89-117.

https://regionetdeveloppement.univ-tln.fr/wp-content/uploads/5-Gakpa.pdf

Gérard, C. (2006). Croissance économique et b-Bien-Etre. Revue de l'OFCE, 96, 11-34.

Gouenet, M.-R. (2009). Instabilité sociopolitique et niveau de l'investissement privé: Une évaluation empirique du cas du Cameroun. CAHIER DU CEDIMES, 3, 37-50.

Gupta, D. K. (1991). On the Methodology of Constructing a Composite Indicator for Political Instability: A Cross-National Study. In R. Frantz, H. Singh, \& J. Gerber (Eds.), Handbook of Behavioral Economics (Vol. 2A, pp. 151-178). JAI Press Inc.

Gurgul, H., \& Lach, Ł. (2013). Political Instability and Economic Growth: Evidence from Two Decades of Transition in CEE. Communist and Post-Communist Studies, 46, 189-202. https://doi.org/10.1016/j.postcomstud.2013.03.008

Haan, J., \& Siermann, C. L. J. (1996). Political Instability, Freedom and Economic Growth: Some Further Evidence. Economic Development and Cultural Change, 44, 339-350. https://doi.org/10.1086/452217

Kouassi, Ya. A. G. (2021). Analyse des effets du capital santé sur la croissance économique en Côte d'Ivoire. International Journal of Financial Accountability, Economics, Management, and Auditing, 3, 118-131. https://doi.org/10.52502/ijfaema.v3i3.72

Kuma, J. K. (2018). Modélisation ARDL, Test de cointégration aux bornes et Approche de Toda-Yamamoto: éléments de théorie et pratiques sur logiciels. (à ajouter dans la bibliographie)

Londregan, J. B., \& Poole, K. T. (1990). Poverty, the Coup Trap, and the Seizure of Executive Power. World Politics, 42, 151-183. https://doi.org/10.2307/2010462

Loots, E. (1998). Job Creation and Economic Growth. South African Journal of Economics, 66, 319-336. https://doi.org/10.1111/j.1813-6982.1998.tb01256.x

Lucas R., (1988). On the Mechanics of Economic Development. Journal of Monetary Economics, 22, 3-42. https://doi.org/10.1016/0304-3932(88)90168-7

Makrem, B., \& Faycel, R. (2018). Démocratie, stabilité politique et croissance économique: Estimation à partir d'un modèle en panel dynamique, l'actualité économique. Revue d'analyse économique, 94, 55-89. https://doi.org/10.7202/1065756ar

Mauro, P. (1995). Corruption and Growth. Quarterly Journal of Economics, 110, 681-712. https://doi.org/10.2307/2946696

Muñoz, R. (2009). Political Instability and Economic Growth: The Case of Venezuela (1983-2000). Documentos de Trabajo.

http://www.redeconomia.org.ve/redeconomia/admin_redeconomia/uploads/general/p ub892009101433.pdf

Nadia, F., \& Mouana, A. (2017). Effet de l'instabilité des institutions politiques sur la croissance économique en Tunisie: Une approche par le modèle ARDL. International Journal of Economics et Strategic Management of Business Process (ESMB), 8, 148-157.

Ndokang, L., \& Tsambou, A. D. (2019). Instabilité politique en République centrafricaine (RCA) et performance de croissance de l'économie camerounaise. Les Cahiers du CEDIMES, 13, 9-28.

Pesaran, M. H., \& Shin, Y. (1999). An Autoregressive Distributed Lag Modeling Approach to Cointegration Analysis. In S. Strom (Ed.), Econometrics and Economic Theory in the 20th Century (Chapter 11), The Ragnar Frisch Centennial Symposium, 
Cambridge University Press.

Pesaran, M. H., \& Smith, R. (1995). Estimating Long-Run Relationships from Dynamic Heterogeneous Panels. Journal of econometrics, 68, 79-113. https://doi.org/10.1016/0304-4076(94)01644-F

Pesaran, M. H., Shin, Y., \& Smith, R. J. (2001). Bounds Testing Approaches to the Analysis of Level Relationships. Journal of Applied Econometrics, 16, 289-326. https://doi.org/10.1002/jae.616

Romer, P. (1986). Increasing Returns and Long-Run Growth. Journal of Political Economy, 94, 1002-1037. https://doi.org/10.1086/261420

Solow, R. M., (1957). Technical Change and the Aggregate Production Function. Revue of Economics and Statistics, 39, 312-320. https://doi.org/10.2307/1926047

Sosso, F., Samuel, G., Parick, G., Sylviane, G., \& Patrick, P. (2020). Zone franc, croissance économique et réduction de la pauvreté: Fondation pour les études et recherches sur le développement international. Ferdi.

Tabassam, A. H., Hashmi, S. H., \& Rehman, F. U. (2016). Nexus between Political Instability and Economic Growth in Pakistan. Procedia-Social and Behavioral Sciences, 230, 325-334. https://doi.org/10.1016/j.sbspro.2016.09.041 